\title{
THE PRINCIPLES OF THE STATE LAND CONTROL
}

An independent scientist

Tashkent state university of Law, Republic of Uzbekistan Saliev Mirza Abdurachmanovich

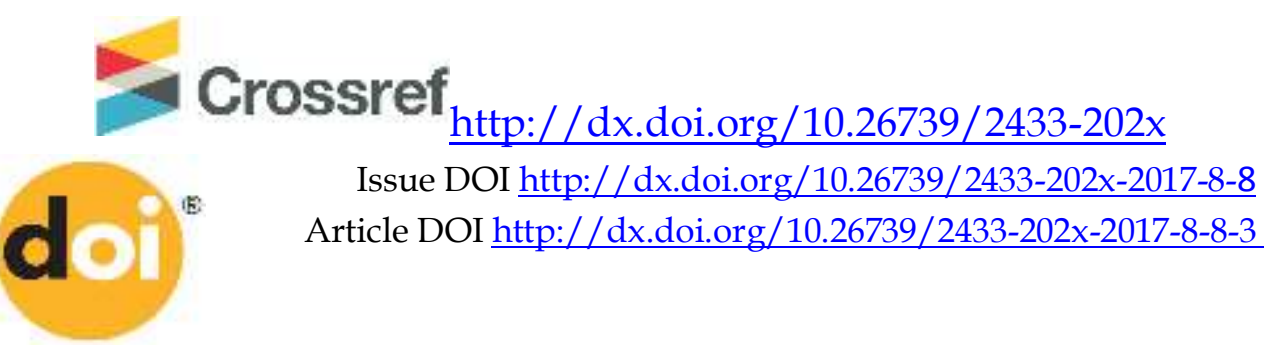

Abstract. In the article, the author examined from the scientific and legal point of view the fundamental principles of conducting state land control, the basic rights, tasks and responsibilities of bodies exercising land control. Based on the study of law enforcement practice, the author developed appropriate proposals and recommendations for improving it.

Keywords. Land Resources, Land Code, State Land Control, Principles, Monitoring, Expertise, Control Methods.

State land control occupies an independent place and tasks in the system of state administration in the sphere of land use and its protection; nevertheless, it cannot be separated from the system of general state functions, since it has inherent special management activities. Although landlegal literature draws serious attention to issues of state administration in the sphere of land use and its protection, in most cases, the principles of state land control remained without due attention, and sometimes were only partially analyzed.

In general, in the dictionary of foreign words and expressions "the Social science and humanities

M.Saliev 
principle (Latin "principium") is fixed as an important, guiding idea, activity, basic rules of conduct"1. As a rule, principles are understood as the main provisions of politics, science, doctrine and worldview ${ }^{2}$.

To study the principles of state control, it is worthwhile to dwell on the general concept of legal principles. Z. Islamov recognizes legal principles as "guiding ideas that characterize the content of law, its content and social significance" 3 . V.V. Yarkov, in his turn, writes that "the principle is a historical category formed during the long development of science, and is a valuable element of human culture. ${ }^{4 \prime}$

As rightly noted in the legal literature, "the principle of law - universal guiding ideas that are fixed in various sources or found expression in a permanent legal practice, simultaneously reflecting the level of knowledge of general social and special laws of law, serving to create an internally balanced and optimal system of legal norms, and also direct regulation of public relations in the presence of gaps and collisions" 5 . The principles of law are the primary foundations of the processes of formation, action and development of law, its main provisions and guiding ideas. The principles of law serve as a kind of powerful foundation for the systems of law ${ }^{6}$.

It is worth emphasizing that the problem of the principles of state control in the system of public administration has been to a certain extent examined by researchers in the field of administrative law (in particular, V.I. Gorshenov, Yu.M. Kozlov, B. M. Lazarev, AF Nozdrachev , V.I.Pronina, A.I.Ryabko, M.S.Studenikina, B.B. Khangeldiev, I.B.Shakhov, E.V.Shorina, C.A. Yampolskaya and others). As correctly stated in these studies, for a full coverage of the essence and content of the principles of control, it is advisable to refer to the general principles of public administration.

So, E.V. Shorina studying the problem writes: “Occupying a special place in the management system, the control function differs from other management functions in its purpose, content, form and ways of its implementation. Therefore, the study of general management principles regarding the control function has its own characteristics, which must be

1Dictionary of foreign words and expressions. / / Authors.- comp. N.V. Trus, TG Shubina. - M .: Literature, 1997

2Skurko E.V. Principles of law. - Moscow: Axis-89, 2008, P.6.

3Islamov Z.M. Хуқуқ тушунчаси, мохияти, ижтимоий вазифаси. Textbook. - T.: TGYuI, 2004, P.77; Islamov Z.M. Society. State. Right. - T.: Adolat, 2001, P.354-355. .

${ }^{4}$ Arbitration process. Textbook. / Ed. Ed. prof. V.V. Yarkov. - Moscow: Publishing house BEK, 2001, p. $32 .$.

${ }^{5}$ Bayniyazova Z.S. The concept and classification of the principles of the Russian legal system. Textbook 2 nd ed., rework. and additional. -Saratov: The scientific book, 2008, P.8

${ }^{6}$ Theory of State and Law: A Course of Lectures .// Ed. M.N. Marchenko. -M.: Mirror, Theis, 1996, P.295 
identified and thoroughly studied. On the other hand, the existence of general principles does not exclude the existence of special principles of control" 7 .

In the legal literature to date there is no common understanding of the principles of control, there are no uniform criteria for the systematization of control principles. V.I Zaluzhny includes in a number of principles of control publicity, publicity, constancy, all-roundness and impartiality. ${ }^{8}$ V.Volovych and N.I. Kuznetsov, in their turn, recognize publicity, publicity, comprehensiveness, stimulation of positive experience, seriousness, efficiency, legality, expediency, effectiveness as principles of control. ${ }^{9}$

In our opinion, it is difficult to assess effectiveness, expediency and effectiveness as principles of control, including land control. At the same time, they are not the principles of control, but its goals. For, as a rule, the universal governing rules are recognized as a principle, which express not the properties of constituent parts, but rather, the properties that encompass the whole aggregate of certain social relations. In addition, it is not possible to adopt the principles of control to stimulate positive experiences and seriousness, since they are the usual conditions for any activity. Of course, without serious and sufficient experience, deep mastery of the law, one should not start fulfilling duties in such a responsible and complex area of activity as land control.

The content of the principles of state land control should be studied, based on general principles of public administration and control. In particular, such can be considered the principles of legality and glasnost, which belong to the category of universal principles, without which it is impossible to effectively implement state control over the implementation of land reforms in the country, rational use and protection of land. So, these principles - lawfulness and glasnost are closely interrelated among themselves. It is known that any control can give the expected effect only if it is implemented on the basis of law, as well as the transparency of the monitored activity. This requirement extends to the whole system of the state apparatus, including the sphere of use of land, water, forests and other objects of nature.

One of the generally recognized principles of control is the participation of the public in exercising supervisory functions, this principle

\footnotetext{
7 Shorina E.V. Control over the activities of government. - M., 1981. - P.63.

8 Zaluzhny V.I. People's control in modern conditions. - M .: Thought, 1970. - P.45-50.

${ }^{9}$ Volovich V.K., Kuznetsov N.I. People's control in the Armed Forces. -M.: Vos from-dates, 1973.- P. 9-22
}

Social science and humanities

M.Saliev 
can combine state and public control.

In order to ensure the effectiveness of state land control, it is necessary to pay attention to its following principles: firstly, the complexity of the relations of state land control, in accordance with it, the object and subject composition of these relations have a public legal and private legal character; secondly, the principle of separation of powers that ensure the independence of the legislative, executive and judicial authorities in control activities should be taken into account, in accordance with it, state land control should be carried out only within the competence defined by law. Particular emphasis should be placed on parliamentary control. Deputies have the right to apply to state bodies, officials, enterprises, organizations and institutions in the framework of their activities, including on the implementation of laws in the field of land use, land protection; Thirdly, it is necessary to liquidate numerous controlling bodies and ensure the implementation or coordination of the function of land control by a single specially authorized state body; Fourth, comprehensive, public control - in the legal literature this principle is also treated as the principle of "universality" (universalism), since it covers landowners and land users of all categories, regardless of subordination and forms of economic management (owner, tenant, owner land, land user) 10; Fifth, the independence of controlling bodies (state, public, audit, contractual) from controlled enterprises, organizations and institutions. If the controlling bodies are not independent in their decisions, they will feel pressure from the controlled entities, it is not worth talking about the effectiveness of control, the positivity of its results; sixthly, the restriction of controlling activities from the economic, in accordance with it, the same body cannot implement land use, as well as control over land use. Naturally, the State Committee for Land Resources, Geodesy, Cartography and the State Cadastre of the Republic of Uzbekistan is an independent body in the sphere of public administration and has control functions in the use and protection of land. Therefore, if he is accountable to the Government of the Republic of Uzbekistan, he annually provides him with a report on the state of land use, naturally, he will be interested in improving indicators of the state of land use; and, finally, seventhly, the principle of appropriate legislative activity in the sphere of state land control. In accordance with this principle, the legislation and other regulatory and legal acts aimed at regulating relations in this sphere should take into account changes concerning state land control, in particular, its goals, objectives, principles, types, content, etc.

${ }^{10}$ Land law / Ed. N.D. Kazantsev. - M .: Jurid. lit., 1971. -P.121. 
The definition and clarification of the principles of state land control is important in the creation of its modern scientific concept and the provision of its practical results. They help in the development of the basic rules of state land control, thus serve to formulate state policy in this area. Finding its consolidation in legal norms, these principles, finding the form of normsprinciples (a kind of land-legal norms), can be applied in the regulation of land relations.

In the performance of the functions of state land control, government agencies are guided by the following principles: first, the precise distribution of functions between state bodies and local self-government bodies. In general, the function of land control is entrusted to the State Committee of the Republic of Uzbekistan for land resources, geodesy, cartography and state cadastre, and the function of monitoring environmental safety on land plots is to the State Committee for Nature Protection, and secondly, the inadmissibility of interference by some state bodies in functions of other state bodies, since such interference can lead to red tape, loss of official responsibility for the performance of their tasks.

In determining the principles of state land control, it is worthwhile to bring the principles of environmental law. For, these principles can help in determining the principles of state land control. Thus, according to the principles of environmental law, according to Zh. T. Kholmuminov, "the ideas of the doctrine, fixed in the norms of environmental law and determining its general content, as well as the essence and content of its individual institutions" are understood ${ }^{11}$.

Sh. Kh. Fayziev writes that "The principles of environmental law are important in determining the direction of the relationship in the societynature system, guaranteeing the stability of the environmental and legal mechanism and establishing legislative provisions for the regulation of environmental relations"12. A.Nigmatov, in turn, under the principles of environmental law understands, "guiding or guiding provisions for the legal regulation of environmental relations" 13 .

In our opinion, the principles of the right to use and protect land should be understood as a set of theoretical ideas and provisions reflecting its content and nature and aimed at ensuring that land-use protection requirements are taken into account, which establish on a scientific basis the

11Kholmuminov Zh.T. Уззбекистон Республикасининг экология хуқуқи. Textbook. -T.: Academy of
Ministry of Internal Affairs of Republic of Uzbekistan, 2003, P.10.
${ }^{12 E k o l o g i c a l ~ L a w: ~ T e x t b o o k . ~ E d i t .: ~ M . B . ~ U s m o n o v . ~-T .: T D Y u I, ~ 2006, ~ P .45 ~}$
${ }^{13 N i g m a t o v ~ A . N . ~ У з б е к и с т о н ~ Р е с п у б л и к а с и н и н г ~ э к о л о г и я ~ х у қ у қ и . ~ T e x t b o o k . ~-~ T .: T D Y u I, ~ 2006, ~ P .45 ~}$

Social science and humanities

M.Saliev 
use of land resources in close interrelation with the necessary measures aimed at on the legal settlement of law enforcement in the sphere of land relations, fixed in the norms of land law.

The principles of state land control are reflected in the current land legislation. Thus, Article 4 of the Law "On Nature Protection" defines ten rules for achieving the objectives of nature protection, which in their content also constitute the principles of land law. Also, Article 2 of the Land Code provides for eight basic principles of acts of land legislation.

In them, as separate principles of land use rights, the right to use under state control, the independence of the right to use, the need for rational land use, targeted use of land, effective land use, its stability, and the need to maintain certain stability are indicated.

In the sphere of relations of state land control among general principles, including the settlement of land use as an object of nature, a social and economic object; ensuring the diversity of forms of ownership and use of land; ensuring equal rights for participants in land relations and protecting their rights; inadmissibility of unlawful interference of state departments in the activities of legal entities and individuals in the possession, use and disposal of land plots; prevention of damage to land and the entire environment; prevention of actions that violate the rights and legitimate interests of landowners and land users; obligatory of all measures concerning state management of the land fund irrespective of the forms of the right to land. The above are the basic principles of land control, all state bodies (legislative, executive, judicial bodies, prosecutors, etc.) must strictly follow them in their activities. 


\section{References}

Dictionary of foreign words and expressions. / / Authors.- comp. N.V. Trus, TG Shubina. - M .: Literature, 1997

Skurko E.V. Principles of law. - Moscow: Axis-89, 2008, P.6.

Islamov Z.M. Хуқуқ тушунчаси, мохияти, ижтимоий вазифаси. Textbook. - T.: TGYuI, 2004, P.77; Islamov Z.M. Society. State. Right. - T.: Adolat, 2001, P.354-355..

Arbitration process. Textbook. / Ed. Ed. prof. V.V. Yarkov. - Moscow:

Publishing house BEK, 2001, p. 32.

Bayniyazova Z.S. The concept and classification of the principles of the Russian legal system. Textbook 2 nd ed., rework. and additional. -Saratov: The scientific book, 2008, P.8

Theory of State and Law: A Course of Lectures. // Ed. M.N. Marchenko. -M.: Mirror, Theis, 1996, P.295

Shorina E.V. Control over the activities of government. - M., 1981. - P.63.

Zaluzhny V.I. People's control in modern conditions. - M .: Thought, 1970. P.45-50.

Volovich V.K., Kuznetsov N.I. People's control in the Armed Forces. -M.: Vos from-dates, 1973.- P. 9-22

Land law / Ed. N.D. Kazantsev. - M .: Jurid. lit., 1971. -P.121.

Kholmuminov Zh.T. Узбекистон Республикасининг экология хуқуқи.

Textbook. -T.: Academy of Ministry of Internal Affairs of Republic of

Uzbekistan, 2003, P.10.

Ekological Law: Textbook. Edit.: M.B. Usmonov. -T.:TDYuI, 2006, P.45

Nigmatov A.N. Узбекистон Республикасининг экология хуқуқи. Textbook. - T.:TDYuI, 2006, P.45 